\title{
Effect of Different Post-Harvest Treatments and Prepackaging on Storage Behavior of Guava (Psidium guajava) cv. Khaza
}

\author{
Manisha Ch. Momin*, Jahangir Kabir and Alemmoa R. Jamir \\ Department of Post-Harvest Technology, BidhanChandra Krishi Viswavidyalaya, \\ Mohanpur, Nadia-741252, India \\ *Corresponding author
}

\begin{tabular}{|l|}
\hline Ke y w or d s \\
Package, Aloevera, \\
Salicylic acid, \\
Benzyl adenine, \\
Guava
\end{tabular}

\section{A B S T R A C T}

Guava cv. Khaza is known to have a poor shelf life under ambient storage conditions. But application of post-harvest treatments like Aloevera gel, Salicylic acid and Benzyladenine as post-harvest treatment followed by pre-packaging in polyethylene film of different thickness can enhance shelf life of the fruits. Hence an attempt had been made to judge the efficacy of the treatments with their interaction with packaging practices on shelf life and fruit qualities. Aloevera x 50 $\mu$ LDPE can be used successfully to reduce physiological loss in weight of guava fruits upto $9^{\text {th }}$ day. Benzyl adenine $x 50 \mu$ LDPE was successful in retaining fruit firmness of guava fruits upto $9^{\text {th }}$ day. Most of the interactions were able to ensure fruit colour (light yellow) upto $9^{\text {th }}$ days of storage. The control samples only show change in colour to yellow irrespective of the packaging used. TSS $\left({ }^{\mathrm{O}} \mathrm{B}\right)$ showed a decrease with storage. But the rate of decline was lesser in case of Benzyl adenine $\mathrm{x} 50 \mu$ LDPE $\left(6.9^{\circ} \mathrm{B}\right)$ followed by Aloevera gel x $50 \mu \operatorname{LDPE}\left(6.83^{\circ} \mathrm{B}\right)$. The decline in titratable acidity was lesser in Salicylic acid x $25 \mu$ LDPE (0.363). Ascorbic acid content fall drastically with storage but lesser decline was observed in Aloevera x 50 $\mu$ LDPE (133.01), Aloevera gel x $25 \mu$ LDPE (126.59), Benzyl adenine x $25 \mu$ LDPE (126.58) and Salicylic acid x Aloevera gel (118.33). Hedonic scores based on organoleptic properties were maximum in $\mathrm{T}_{3} \mathrm{P}_{1}(5.87)$ followed by $\mathrm{T}_{1} \mathrm{P}_{1}(5.73)$ at $9^{\text {th }}$ day of storage.

\section{Introduction}

Guava (Psidium guajava L.) is also known as the apple of the tropics. It is one of the most popular fruit grown in the tropical, subtropical and some parts of arid regions of India. Guava is one of the most important fruit crop. India is the leading producer of guava in the world. At present, it ranks fifth among the fruits grown in India occupying 2.55 lakh hectare area with annual production of 4.1 million tonnes (Anonymous, 2015). The fruit is a rich source of Vitamin C and pectin. It is also a good source of calcium, phosphorous, pentothenic acid, riboflavin, thiamine, niacin and vitamin A (Paul and Goo, 1983).

Guava being a climacteric fruit ripens rapidly and is highly perishable, a shelf-life period ranges from 3-4 days at room temperatures. So, it makes transportation and storage difficult (Bassetto et al., 2005). Moreover, 
during storage fruit ripening is characterized by green color loss, rot development, fruit softening, wilting, loss of brightness and undesirable biochemical changes (Jacomino et $a l ., 2001)$. Retailing of guava fruit in India is usually carried out without refrigeration and therefore, the preservation of fruit at room temperature is highly desirable to reduce postharvest loss and improve its commercialization. The post-harvest loss of guava in India is about $25-30 \%$ i.e. 4.5 lakh tonnes, worth rupees180 crores (Patel et al., 2014). The post-harvest losses can be minimized by checking the rate of transpiration and respiration, microbial infection and protecting membranes from disorganization (Bisen and Pandey, 2008). Post-harvest dipping treatment increases the shelf life of fruits by retaining their firmness and control of the decaying organism (Ahmed et al., 2009).

Recently, interest has increased in using Aloevera gel-based edible coating material for fruits and vegetables. This gel is tasteless, colorless and odourless. Aloevera gel has been proven one of the best edible and biologically safe preservative coatings for different types of foods because of its film-forming properties, antimicrobial actions and biodegradability and biochemical properties. It is composed mainly of polysaccharides and acts as a natural barrier to moisture and oxygen, which are the main agents of deterioration of fruits and vegetables (Misir et al., 2014). Aloevera gel coatings have a various favorable effect on fruits such as imparting a glossy appearance and better color, retarding weight loss, or prolonging storage/shelf-life by preventing microbial spoilage (Dang et al., 2008) and has found to be effective in fruits such as table grapes (Castillo et al., 2010), sweet cherries (Martinez et al., 2006) and nectarines (Ahmed et al., 2009). Aloevera gel has not been tried in guava earlier. Mani et al., (2017) have found that aloevera gel when used in ber cv. Umran can successfully enhance its shelf life of upto $15^{\text {th }}$ day of ambient storage.

Salicylic acid, which belongs to a group of phenolic compounds, is widely distributed in plants and it is now considered as a hormonal substance, playing an important role in regulating a large variety of physiological processes. Salicylic acid influenced physiological or biochemical processes including ion uptake, membrane permeability, enzymes activity, heat production, growth and development (Arberg, 1981).

Thus, salicylic acid has remarkable ability to maintain the quality during storage of fruits. Exogenous application of salicylic acid has been determined to delay ripening in a number of fruits by reducing the activities of major cell wall degrading enzymes viz., cellulase, polygalacturonase and xylanase (Srivastava and Dwivedi, 2000) and by suppressing ACC synthase and ACC oxidase (Zhang et al., 2003).

The senescence delaying ability of cytokinins particularly 6-Benzyladenine (BA) has been explored in guava (Jayachandran et al., 2007 and Kumar et al., 2015) lettuce, Brussels sprouts, broccoli and celery (Van Staden and Joughin, 1990). Recently it has been reported that BA acts as antioxidant and has free radical quenching property which inhibited ethylene biosynthesis resulting in retardation of senescence and in many cases effectively reduced weight loss and increased storage period (Apelbaum, 1981 and Jayachandran et al., 2007).

Previous reports indicated the prospect of maintaining quality and increasing shelf-life of guava by packaging with polyethylene film (LDPE) (Kore and Kabir, 2011 and Kaur et al., 2014). Therefore, an attempt has been made to prolong the shelf life of guava fruits using Aloevera gel, Salicylic acid and 
Benzyladenine as post-harvest treatment followed by pre-packaging in polyethylene film of different thickness. The polyethylene packaging further might have concomitant effect in delaying senescence and physiological processes by creating modified atmospheric condition around the produce by controlling the gaseous $\left(\mathrm{CO}_{2}\right.$ and $\left.\mathrm{O}_{2}\right)$ concentration in the package (Neeraj et al., 2003). Considering all the above facts an attempt has been made to study the combine effect of post-harvest treatments and prepackaging on physico-chemical changes during ripening of guava fruits.

\section{Materials and Methods}

\section{Experimental site}

Laboratory of Department of Post-Harvest Technology of Horticultural Crops, faculty of Horticulture, BCKV, Mohanpur, Nadia during the period from February 2017 to March 2017.

\section{Source of material}

Well-developed mature fruits of guava cv. Khaza were harvested at green mature stage in the morning from the well maintained orchard at Ghoragacha village near Mohanpur and immediately brought to the laboratory of Department of Post-Harvest Technology of Horticultural Crops.

\section{Application of Treatments}

\section{Application of Aloevera gel coating}

After separating Aloevera gel from the outer cortex, this colourless hydroparenchyma was blended. This mixture was filtered to remove fibres. The liquid obtained constituted fresh Aloevera gel. Guava fruits were dipped in Aloevera gel: distil water in 1:3 ratio (v:v) for 5 minutes where the specific gravity of Aloevera gel used was 1.02 .

\section{6-Benzyladenine (BA)}

A stock solution of 50ppm Benzyadenine (BA) was prepared by dissolving 50mg of BA in small quantity of $0.1 \mathrm{~N} \mathrm{NaOH}$ and the volume was made up to one litre with distilled water. The fruits were then dipped in the solution of BA for 5 minutes and then taken out and air dried.

\section{Salicylic acid}

A stock solution of 200ppm salicylic acid was prepared by dissolving $200 \mathrm{mg}$ of SA in a small quantity of acetone first and then the volume was made up to $1000 \mathrm{ml}$ or one litre with distilled water.

The guava fruits were then dipped in the stock solution of SA for 5 minutes and then taken out and air dried.

\section{Packaging of treated fruits}

Low density polyethylene bags of $25 \mu$ and $50 \mu$ thickness and $45 \times 30 \mathrm{~cm}$ size with $1 \%$ perforation were used for the experiment. The size of each perforation was approximately $0.125 \mathrm{~cm}^{2}$.

\section{Experimental details}

Guava fruits after preparation were subjected to different treatment combination of growth substances (SA and BA) and Aloevera gel for 5 minutes. Each treatment was replicated four times.

\section{Treatment details}

The treatments are actually the varied combinations of different treatments and the packaging materials employed. The different combinations are $\mathrm{T}_{1} \mathrm{P}_{1}=$ Aloevera gel: water (1:3) with LDPE $25 \mu ; \mathrm{T}_{1} \mathrm{P}_{2}=$ Aloevera gel: water (1:3) with LDPE $50 \mu ; \mathrm{T}_{2} \mathrm{P}_{1}=$ Salicylic 
acid 200ppm with LDPE $25 \mu ; \mathrm{T}_{2} \mathrm{P}_{2}=$ Salicylic acid 200ppm with LDPE $50 \mu ; \mathrm{T}_{3} \mathrm{P}_{1}=6$ -

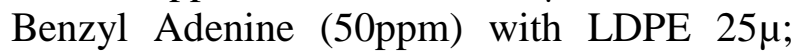
$\mathrm{T}_{3} \mathrm{P}_{2}=6$-Benzyl Adenine (50ppm) with LDPE $50 \mu ; \mathrm{T}_{4} \mathrm{P}_{1}=$ Control + LDPE $25 \mu$ and $\mathrm{T}_{4} \mathrm{P}_{2}=$ Control + LDPE $50 \mu$.

\section{Design of experiment}

Two Factor Factorial Completely Randomized design was adopted where Factor 1 is the number of treatments (4) and Factor 2 is the thickness of LDPE (2). Hence the total numbers of treatment combinations were 8 , with 4 replications each. The total number of fruits taken per replications was 8. SPSS 21 software was used to analyze the data statistically.

\section{Parameters analyzed}

Different parameters were analyzed for their physical, bio-chemical and organoleptic properties on $3^{\text {rd }}, 5^{\text {th }}$ and $9^{\text {th }}$ day of storage.

\section{Physical properties of fruits}

\section{Physiological loss in weight (PLW \%)}

For determining the physiological loss in weight, fruits were numbered and weighed individually on the day of observation. It was expressed as percentage of the original fresh weights of the fruit.

Initial fruit weight - final weight of the fruit PLW $(\%)=$

$$
\text { Initial fruit weight }
$$

\section{Fruit firmness}

Penetrometer (Model no. FT-327) was used to determine the firmness of the representative sample by puncturing at three different places of fruit (upper, middle and lower portion). Average firmness was expressed as $\mathrm{kg} / \mathrm{cm}^{2}$.

\section{Biochemical properties}

\section{Total soluble solids ( ${ }^{0}$ Brix)}

TSS value of the fruit was determined by hand refractometer.

Acidity (\%)

The acidity and ascorbic acid were estimated by the method described by Rangana.

\section{Ascorbic acid (mg/100g)}

The acidity and ascorbic acid were estimated by the method described by Rangana.

\section{Organoleptic evaluation of fruits}

Organoleptic evaluation was recorded of physical characters of fruits viz., fruit appearance (colour), taste, firmness and flavour by a panel of judges as per "hedonic scale" 1-9 point according to Rajkumar et al., (2006).

\section{Results and Discussion}

Table 1 shows the interaction between treatments and polyethylene thickness on PLW revealed non-significant effect on $3^{\text {rd }}$ and $6^{\text {th }}$ day and significant effect on $9^{\text {th }}$ day of storage. Low PLW was observed in the interaction treatment of $\mathrm{T}_{1} \mathrm{P}_{2}$ (Aloevera gel $\times$ $50 \mu$ LDPE) and $\mathrm{T}_{2} \mathrm{P}_{2}$ (Salicylic acid $\times 50 \mu$ LDPE $)$ on $3^{\text {rd }}$ day $(0.67 \%$ and $0.88 \%$ respectively) and $6^{\text {th }}$ day $(1.67 \%$ and $1.62 \%$ respectively). On $9^{\text {th }}$ day PLW was significantly low $(3.22 \%)$ in $\mathrm{T}_{1} \mathrm{P}_{2}$ (Aloevera gel $\times 50 \mu$ LDPE), followed by $3.83 \%$ in $\mathrm{T}_{3} \mathrm{P}_{2}$ (Benzyladenine $\times 50 \mu$ LDPE), $3.97 \%$ in $\mathrm{T}_{2} \mathrm{P}_{1}$ (Salicylic acid $\times 25 \mu \mathrm{LDPE}$ ), $4.20 \%$ in $\mathrm{T}_{1} \mathrm{P}_{1}$ (Aloevera gel $\times 25 \mu \mathrm{LDPE}$ ) and so on in that increasing order. $\mathrm{T}_{4} \mathrm{P}_{1}$ (Control $\left.\times 25 \mu \mathrm{LDPE}\right)$ exhibited highest PLW of $5.60 \%$ on $9^{\text {th }}$ day. PLW of $\mathrm{T}_{1} \mathrm{P}_{2}$ (Aloevera gel $\left.\times 50 \mu \mathrm{LDPE}\right)$ and 
$\mathrm{T}_{3} \mathrm{P}_{2}$ (Benzyladenine $\times 50 \mu$ LDPE) was not significantly different and the two interaction treatments were at par.

Table 2 depicts the combined effect of treatments $\times$ LDPE thickness indicated significant effect on the $3^{\text {rd }}$ and $6^{\text {th }}$ day of storage and non- significant on $9^{\text {th }}$ day of storage (Table 5). On $3^{\text {rd }}$ day firmness of combination $\mathrm{T}_{2} \mathrm{P}_{1}$ (Salicylic acid $\times 25 \mu$ LDPE) was observed to be maximum (3.47 $\mathrm{kg} / \mathrm{cm}^{2}$ ). This was followed by $\mathrm{T}_{1} \mathrm{P}_{2}$ (Aloevera gel $\times 50 \mu$ LDPE), $\mathrm{T}_{1} \mathrm{P}_{1}$ (Aloevera gel $\times 25 \mu$ $\mathrm{LDPE}), \mathrm{T}_{4} \mathrm{P}_{1}$ (control $\times 25 \mu \mathrm{LDPE}$ ) and so on in decreasing order. However, there was no significant difference between these treatments and these treatment combinations were at par on the $3^{\text {rd }}$ day of storage.

Firmness declined steadily in combined treatments of $\mathrm{T}_{1} \mathrm{P}_{1}$ (Aloevera gel $\times 25 \mu$ $\mathrm{LDPE}), \mathrm{T}_{1} \mathrm{P}_{2}$ (Aloevera gel $\left.\times 50 \mathrm{LDPE}\right), \mathrm{T}_{3} \mathrm{P}_{2}$ (Benzyladenine $\times 50 \mu \mathrm{LDPE})$ and retained higher firmness than $\mathrm{T}_{4} \mathrm{P}_{1}$ (control $\times 25 \mu$ LDPE) and $\mathrm{T}_{4} \mathrm{P}_{2}$ (control $\times 50 \mu$ LDPE) on the $6^{\text {th }}$ and $9^{\text {th }}$ day of storage. It was further observed that $\mathrm{T}_{1} \mathrm{P}_{1}$ (Aloevera gel $\times 25 \mu$ LDPE) possessed significantly higher firmness compared to all other treatment combinations on $6^{\text {th }}$ day of storage and it also maintained higher firmness on the $9^{\text {th }}$ day of storage. The firmness of $\mathrm{T}_{4}$ (Control) reduced abruptly to $1.30 \mathrm{~kg} / \mathrm{cm}^{2}$.

Table 3 shows the interaction effect of treatments and polyethylene thickness on visual colour change of the fruits. At $3^{\text {rd }}$ day of storage the guava fruit colour was green in T1P1, T2P1, T2P2; light green in T1P2, T3P1, T3P2 and T4P2. At $6^{\text {th }}$ day of storage, The fruit colour changed fro, light green to green in T1P1, T2P1 and T2P2; light yellow tinge was observed in fruits of T1P2 and T3P2; creamy light green in T3P1; light yellow in T4P1 and T4P2. At $9^{\text {th }}$ days of storage T1P1, T1P2, T2P1, T2P2 and T3P3 were light yellow in colour whereas T3P1, T4P1 AND T4P2 showed yellow coloured fruits.

Table 4 shows the interaction effect of treatments and polyethylene thickness has been presented. The interaction effect was non- significant on the $9^{\text {th }}$ day of storage while on $3^{\text {rd }}$ and $6^{\text {th }}$ day it was significant. On $3^{\text {rd }}$ day the combined effect of $\mathrm{T}_{1} \mathrm{P}_{1}$ (Aloevera gel $\times$ $25 \mu$ LDPE) and $\mathrm{T}_{2} \mathrm{P}_{1}$ (Salicylic acid $\times 25 \mu$ LDPE) recorded maximum TSS of $9.26^{\circ}$ Brix followed by $8.86^{\circ}$ Brix in $\mathrm{T}_{4} \mathrm{P}_{1}$ (control $\times 25 \mu$ LDPE), $8.53{ }^{\circ}$ Brix in $\mathrm{T}_{2} \mathrm{P}_{2}$ (Salicylic acid $\times$ $50 \mu$ LDPE) $8.46^{\circ}$ Brix in $\mathrm{T}_{3} \mathrm{P}_{1}$ (Benzyladenine $\times 25 \mu$ LDPE), $8.33{ }^{\circ}$ Brix in $\mathrm{T}_{1} \mathrm{P}_{2}$ (Aloevera gel $\times 50 \mu \mathrm{LDPE}$ ), etc, on that decreasing order. TSS of $\mathrm{T}_{4} \mathrm{P}_{1}$ reduced abruptly to 6.40 ${ }^{\circ}$ Brix on $6^{\text {th }}$ day, followed by $6.23^{\circ}$ Brix on $9^{\text {th }}$ day. On $6^{\text {th }}$ day the TSS of the combination $\mathrm{T}_{1} \mathrm{P}_{1}$ (8.06 $\left.{ }^{\circ} \mathrm{Brix}\right), \mathrm{T}_{2} \mathrm{P}_{1}\left(8.33^{\circ} \mathrm{Brix}\right), \mathrm{T}_{2} \mathrm{P}_{2}$ (7.86 $\left.{ }^{\circ} \mathrm{Brix}\right)$ were significantly higher than the combination of control with thickness i.e., $\mathrm{T}_{4} \mathrm{P}_{1}\left(6.4^{\circ} \mathrm{Brix}\right)$ and $\mathrm{T}_{4} \mathrm{P}_{2}\left(7.06^{\circ} \mathrm{Brix}\right)$. Other interaction treatments for TSS on $6^{\text {th }}$ day like $\mathrm{T}_{1} \mathrm{P}_{2}, \mathrm{~T}_{3} \mathrm{P}_{2}, \mathrm{~T}_{3} \mathrm{P}_{1}$ were significantly higher than the combination of control with lower thickness i.e., $\mathrm{T}_{4} \mathrm{P}_{1}$.

On $9^{\text {th }}$ day although there was no significant difference between interaction treatment on TSS, however, $\mathrm{T}_{3} \mathrm{P}_{2}$ (Benzyladenine $\times 50 \mu$ LDPE) retained maximum TSS of $6.90^{\circ} \mathrm{Brix}$ followed by $\mathrm{T}_{1} \mathrm{P}_{2}$ (Aloevera gel $\times 50 \mu \mathrm{LDPE}$ ) of $6.83^{\circ}$ Brix, $\mathrm{T}_{3} \mathrm{P}_{1}$ (6.63 $\left.{ }^{\circ} \mathrm{Brix}\right), \mathrm{T}_{2} \mathrm{P}_{1}$ (6.51 ${ }^{\circ}$ Brix $), \mathrm{T}_{1} \mathrm{P}_{1}\left(6.50{ }^{\circ} \mathrm{Brix}\right)$ and so on in that decreasing order.

The interaction effect of treatment and thickness for titratable acidity is shown in Table 9. The interaction effect of titratable acidity was significant at $5 \%$ level on $3^{\text {rd }}, 6^{\text {th }}$ and $9^{\text {th }}$ day of storage. It was observed that combined effect of $\mathrm{T}_{3} \mathrm{P}_{1}$ (Benzyladenine $\times$ $25 \mu$ LDPE) retained higher acidity during early period of storage i.e., $3^{\text {rd }}$ day $(0.389 \%)$ and $6^{\text {th }}$ day $(0.369 \%)$. 
Table.1 Interaction effect of different treatments and polyethylene thickness on physiological loss in weight (\%) of guava during storage

\begin{tabular}{|c|c|c|c|}
\hline \multirow{3}{*}{ Treatments } & \multicolumn{3}{|c|}{ Storage period (days) } \\
\hline & \multicolumn{3}{|c|}{ PLW (\%) } \\
\hline & $3^{\text {rd day }}$ & $6^{\text {th }}$ day & $9^{\text {th }}$ day \\
\hline $\mathbf{T}_{1} \mathbf{P}_{1}$ & 0.94 & 2.12 & 4.20 \\
\hline $\mathbf{T}_{1} \mathbf{P}_{2}$ & 0.67 & 1.67 & 3.22 \\
\hline $\mathbf{T}_{2} \mathbf{P 1}$ & 1.34 & 1.88 & 3.97 \\
\hline $\mathbf{T}_{2} \mathbf{P}_{2}$ & 0.88 & 1.62 & 4.69 \\
\hline $\mathbf{T}_{3} \mathbf{P}_{1}$ & 1.02 & 2.63 & 4.53 \\
\hline $\mathbf{T}_{3} \mathbf{P}_{2}$ & 1.62 & 2.62 & 3.83 \\
\hline $\mathbf{T}_{4} \mathbf{P}_{1}$ & 1.42 & 2.75 & 5.60 \\
\hline $\mathbf{T}_{4} \mathbf{P}_{2}$ & 1.8 & 2.74 & 4.91 \\
\hline S. Em \pm & 0.278 & 0.298 & 0.229 \\
\hline C.D at 0.05 & N.S & N.S & 0.694 \\
\hline
\end{tabular}

$\mathrm{T} 1=$ Aloevera gel, $\mathrm{T} 2=$ Salicylic acid, T3 $=$ Benzyl adenine, $\mathrm{T} 4=$ Control, $\mathrm{P} 1=25 \mu \mathrm{LDPE}, \mathrm{P} 2=50 \mu \mathrm{LDPE}$

Table.2 Interaction effect of different treatments and polyethylene thickness on firmness of guava during storage

\begin{tabular}{|c|c|c|c|}
\hline \multirow{3}{*}{ Treatments } & \multicolumn{3}{|c|}{ Storage period (days) } \\
\hline & \multicolumn{3}{|c|}{ Firmness $\left(\mathrm{Kg} / \mathrm{cm}^{2}\right)$} \\
\hline & $3^{\text {rd }}$ day & $6^{\text {th }}$ day & $9^{\text {th }}$ day \\
\hline$\overline{T_{1} P_{1}}$ & 2.97 & 2.70 & 1.43 \\
\hline$\overline{T_{1} \mathbf{P}_{2}}$ & 3.03 & 1.83 & 1.33 \\
\hline $\mathbf{T}_{2} \mathbf{P 1}$ & 3.47 & 1.70 & 1.42 \\
\hline $\mathbf{T}_{2} \mathbf{P}_{2}$ & 1.90 & 1.40 & 1.35 \\
\hline $\mathbf{T}_{3} \mathbf{P}_{1}$ & 2.27 & 1.33 & 1.20 \\
\hline $\mathbf{T}_{3} \mathbf{P}_{2}$ & 1.90 & 1.83 & 1.45 \\
\hline $\mathbf{T}_{4} \mathbf{P}_{1}$ & 2.80 & 1.70 & 1.40 \\
\hline $\mathbf{T}_{4} \mathbf{P}_{2}$ & 1.93 & 1.73 & 1.20 \\
\hline S. Em \pm & 0.23 & 0.18 & 0.09 \\
\hline C.D at 0.05 & 0.69 & 0.54 & N.S \\
\hline
\end{tabular}

$\mathrm{T} 1=$ Aloevera gel, $\mathrm{T} 2=$ Salicylic acid, $\mathrm{T} 3=$ Benzyl adenine, $\mathrm{T} 4=$ Control, $\mathrm{P} 1=25 \mu \mathrm{LDPE}, \mathrm{P} 2=50 \mu \mathrm{LDPE}$

Table.3 Interaction effect of different treatments and polyethylene thickness on colour of guava during storage

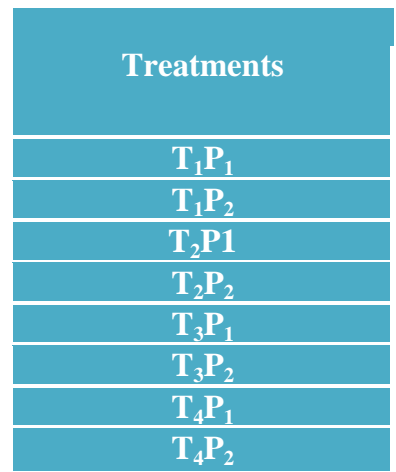

\begin{tabular}{|c|c|c|}
\hline \multicolumn{3}{|c|}{ Storage period (days) } \\
\hline \multicolumn{3}{|c|}{ Colour (visual observation) } \\
\hline $3^{\text {rd day }}$ & $6^{\text {th }}$ day & $9^{\text {th }}$ day \\
\hline Green & Light green & Light yellow \\
\hline Light green & Light yellow tinge & Light yellow \\
\hline Green & Light green & Light yellow \\
\hline Green & Light green & Light yellow \\
\hline Light green & Creamy light green & Yellow \\
\hline Light green & Light yellow tinge & Light yellow \\
\hline Creamy light green & Light yellow & Yellow \\
\hline Light green & Light yellow & Yellow \\
\hline
\end{tabular}

$\mathrm{T} 1=$ Aloevera gel, $\mathrm{T} 2=$ Salicylic acid, $\mathrm{T} 3=$ Benzyl adenine, $\mathrm{T} 4=$ Control, $\mathrm{P} 1=25 \mu \mathrm{LDPE}, \mathrm{P} 2=50 \mu \mathrm{LDPE}$ 
Table.4 Interaction effect of different treatments and polyethylene thickness on TSS $\left({ }^{\mathrm{O}} \mathrm{B}\right)$ of guava during storage

\begin{tabular}{|c|c|c|c|}
\hline \multirow{3}{*}{ Treatments } & \multicolumn{3}{|c|}{ Storage period (days) } \\
\hline & \multicolumn{3}{|c|}{$\operatorname{TSS}\left({ }^{\circ} \mathrm{B}\right)$} \\
\hline & $3^{\text {rd }}$ day & $6^{\text {th }}$ day & $9^{\text {th }}$ day \\
\hline$\overline{T_{1} P_{1}}$ & 9.26 & 8.06 & 6.50 \\
\hline $\mathbf{T}_{1} \mathbf{P}_{2}$ & 8.33 & 7.66 & 6.83 \\
\hline $\mathrm{T}_{2} \mathbf{P 1}$ & 9.26 & 8.33 & 6.53 \\
\hline $\mathbf{T}_{2} \mathbf{P}_{2}$ & 8.53 & 7.86 & 6.26 \\
\hline $\mathbf{T}_{3} \mathbf{P}_{1}$ & 8.46 & 7.13 & 6.63 \\
\hline $\mathbf{T}_{3} \mathbf{P}_{2}$ & 7.93 & 7.53 & 6.90 \\
\hline $\mathbf{T}_{4} \mathbf{P}_{1}$ & 8.86 & 6.40 & 6.23 \\
\hline $\mathbf{T}_{4} \mathbf{P}_{2}$ & 7.93 & 7.06 & 5.93 \\
\hline S. Em \pm & 0.194 & 0.217 & 0.275 \\
\hline C.D at 0.05 & 0.613 & 0.657 & N.S \\
\hline
\end{tabular}

$\mathrm{T} 1=$ Aloevera gel, $\mathrm{T} 2=$ Salicylic acid, T3 = Benzyl adenine, $\mathrm{T} 4=$ Control, $\mathrm{P} 1=25 \mu$ LDPE, P2 $=50 \mu \mathrm{LDPE}$

Table.5 Interaction effect of different treatments and polyethylene thickness on titratable acidity of guava pulp during storage

\begin{tabular}{|c|c|c|c|}
\hline \multirow{3}{*}{ Treatments } & \multicolumn{3}{|c|}{ Storage period (days) } \\
\hline & \multicolumn{3}{|c|}{ Titratable acidity (\%) } \\
\hline & $3^{\text {rd }}$ day & $6^{\text {th }}$ day & $9^{\text {th }}$ day \\
\hline $\mathbf{T}_{1} \mathbf{P}_{1}$ & 0.341 & 0.327 & 0.289 \\
\hline$T_{1} P_{2}$ & 0.362 & 0.346 & 0.309 \\
\hline $\mathrm{T}_{2} \mathrm{P1}$ & 0.362 & 0.341 & 0.363 \\
\hline$T_{2} \mathbf{P}_{2}$ & 0.336 & 0.245 & 0.242 \\
\hline $\mathbf{T}_{3} \mathbf{P}_{1}$ & 0.389 & 0.369 & 0.270 \\
\hline $\mathbf{T}_{3} \mathbf{P}_{2}$ & 0.288 & 0.277 & 0.229 \\
\hline $\mathbf{T}_{4} \mathbf{P}_{1}$ & 0.303 & 0.274 & 0.227 \\
\hline $\mathbf{T}_{4} \mathbf{P}_{2}$ & 0.325 & 0.304 & 0.209 \\
\hline S. Em \pm & 0.021 & 0.014 & 0.020 \\
\hline C.D at 0.05 & 0.065 & 0.042 & 0.060 \\
\hline
\end{tabular}

$\mathrm{T} 1=$ Aloevera gel, $\mathrm{T} 2=$ Salicylic acid, $\mathrm{T} 3=$ Benzyl adenine, $\mathrm{T} 4=$ Control, $\mathrm{P} 1=25 \mu \mathrm{LDPE}, \mathrm{P} 2=50 \mu \mathrm{LDPE}$

Table.6 Interaction effect of different treatments and polyethylene thickness on ascorbic acid of guava during storage

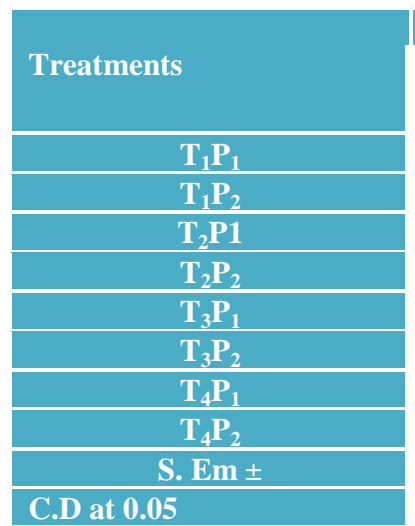

\begin{tabular}{|c|c|}
\hline \multicolumn{2}{|c|}{ Storage period (days) } \\
\hline \multicolumn{2}{|c|}{ Ascorbic acid (mg/100g) } \\
\hline $\mathbf{6}^{\text {th }} \mathbf{d a y}$ & $\mathbf{9}^{\text {th }}$ day \\
\hline 162.98 & 126.59 \\
\hline 174.22 & 133.01 \\
\hline 175.34 & 118.33 \\
\hline 174.21 & 99.98 \\
\hline 174.60 & 126.58 \\
\hline 139.37 & 86.68 \\
\hline 147.23 & 80.72 \\
\hline 139.37 & 76.13 \\
\hline $\mathbf{5 . 5 3}$ & $\mathbf{9 . 4 0 9}$ \\
\hline $\mathbf{1 6 . 7 1}$ & $\mathbf{2 9 . 6 5 0}$ \\
\hline
\end{tabular}

$\mathrm{T} 1=$ Aloever $a$ gel, $\mathrm{T} 2=$ Salicylic acid, $\mathrm{T} 3=$ Benzyl adenine, $\mathrm{T} 4=$ Control, $\mathrm{P} 1=25 \mu \mathrm{LDPE}, \mathrm{P} 2=50 \mu \mathrm{LDPE}$ 
Table.7 Interaction effect of different treatments and polyethylene thickness on organoleptic properties of guava during storage

\begin{tabular}{|c|c|c|c|}
\hline \multirow{3}{*}{ Treatments } & \multicolumn{3}{|c|}{ Storage period (days) } \\
\hline & \multicolumn{3}{|c|}{ Taste perception } \\
\hline & $3^{\text {rd }}$ day & $6^{\text {th }}$ day & $9^{\text {th }}$ day \\
\hline$\overline{T_{1} P_{1}}$ & 7.77 & 7.28 & 5.73 \\
\hline $\mathbf{T}_{1} \mathbf{P}_{2}$ & 7.77 & 7.03 & 5.27 \\
\hline $\mathbf{T}_{2} \mathbf{P 1}$ & 7.85 & 6.83 & 5.43 \\
\hline $\mathbf{T}_{\mathbf{2}} \mathbf{P}_{2}$ & 7.80 & 6.70 & 4.00 \\
\hline$\overline{\mathbf{T}_{3} \mathbf{P}_{1}}$ & 7.68 & 6.95 & 5.87 \\
\hline $\mathbf{T}_{3} \mathbf{P}_{2}$ & 7.98 & 6.93 & 5.00 \\
\hline $\mathbf{T}_{4} \mathbf{P}_{1}$ & 7.50 & 6.38 & 4.00 \\
\hline $\mathbf{T}_{4} \mathbf{P}_{2}$ & 7.57 & 6.35 & 3.83 \\
\hline S. Em \pm & 0.190 & 0.322 & 0.420 \\
\hline C.D at 0.05 & N.S & N.S & N.S \\
\hline
\end{tabular}

$\mathrm{T} 1=$ Aloever $a$ gel, $\mathrm{T} 2=$ Salicylic acid, $\mathrm{T} 3=$ Benzyl adenine, $\mathrm{T} 4=$ Control, $\mathrm{P} 1=25 \mu \mathrm{LDPE}, \mathrm{P} 2=50 \mu \mathrm{LDPE}$

However, during later period of storage particularly on $9^{\text {th }}$ day the combination of $\mathrm{T}_{2} \mathrm{P}_{1}(\mathrm{SA} \times 25 \mu \mathrm{LDPE}), \mathrm{T}_{1} \mathrm{P}_{2}(\mathrm{AVg} \times 50 \mu$ LDPE) and $\mathrm{T}_{1} \mathrm{P}_{1}(\mathrm{AVg} \times 25 \mu \quad \mathrm{LDPE})$ maintained significantly higher acidity in the fruits i.e., $0.363 \%, 0.309 \%$ and $0.289 \%$ respectively compared to control combination i.e., $\mathrm{T}_{4} \mathrm{P}_{1}$ and $\mathrm{T}_{4} \mathrm{P}_{2} \quad 0.227 \%$ and $0.209 \%$ acidity respectively.

Table 6 shows the interaction effect between the treatment and thickness which revealed that $\mathrm{T}_{2} \mathrm{P}_{1}$ (Salicylic acid $\times 25 \mu$ LDPE) possessed significantly high (175.34 $\mathrm{mg} / 100 \mathrm{~g}$ ) ascorbic acid than the control combination with thickness $\left(\mathrm{T}_{4} \mathrm{~T}_{1}\right.$ and $\left.\mathrm{T}_{4} \mathrm{P}_{2}\right)$ on the $5^{\text {th }}$ day of storage. However, there is no significant difference with regard to ascorbic acid content on $5^{\text {th }}$ day between treatment combinations $\mathrm{T}_{1} \mathrm{P}_{1}, \mathrm{~T}_{1} \mathrm{P}_{2}, \mathrm{~T}_{2} \mathrm{P}_{1}, \mathrm{~T}_{2} \mathrm{P}_{2}, \mathrm{~T}_{3} \mathrm{P}_{1}$ thus all these treatments were at par. On the $9^{\text {th }}$ day maximum ascorbic acid $(133.01 \mathrm{mg} /$ $100 \mathrm{~g}$ ) was retained by $\mathrm{T}_{1} \mathrm{P}_{2}$ followed by $\mathrm{T}_{1} \mathrm{P}_{1}$ (126.59 mg/100g), $\mathrm{T}_{3} \mathrm{P}_{1}(126.58 \mathrm{mg} / 100 \mathrm{~g})$, $\mathrm{T}_{2} \mathrm{P}_{1}(118.33 \mathrm{mg} / 100 \mathrm{~g})$ and so on in that decreasing order. The control combination of $\mathrm{T}_{4} \mathrm{P}_{1}$ and $\mathrm{T}_{4} \mathrm{P}_{2}$ possessed less ascorbic acid of
$80.72 \mathrm{mg} / 100 \mathrm{~g}$ and $76.13 \mathrm{mg} / 100 \mathrm{~g}$ respectively.

Interaction between treatments and polyethylene thickness is given in Table 7 . The organoleptic score on $3^{\text {rd }}, 6^{\text {th }}$ and $9^{\text {th }}$ day were non- significant. However, on the last day of storage $\left(9^{\text {th }}\right.$ day) highest organoleptic score was retained by $\mathrm{T}_{3} \mathrm{P}_{1}$ (Benzyl adenine + $25 \mu$ LDPE) followed by $\mathrm{T}_{1} \mathrm{P}_{1}$ (Aloevera gel + $25 \mu$ LDPE), $\mathrm{T}_{2} \mathrm{P}_{2}$ (Salicylic acid $+50 \mu$ LDPE) and so on in that decreasing order.

By considering all the above tables it can be concluded that aloevera $\times 50 \mu$ LDPE can be used successfully to reduce physiological loss in weight of guava fruits upto $9^{\text {th }}$ day. Benzyl adenine $x \quad 50 \mu$ LDPE was successful in retaining fruit firmness of guava fruits upto $9^{\text {th }}$ day. However aloevera x $25 \mu$ LDPE and Salicylic acid x $25 \mu$ LDPE can also ensure good fruit firmness upto $9^{\text {th }}$ days. Most of the interactions were able to ensure fruit colour (light yellow) upto $9^{\text {th }}$ days of storage. The control samples only show change in colour to yellow irrespective of the packaging used. Hence there is a good effect of post-harvest 
treatment on ensuring reduction in chlorophyll degradation. TSS $\left({ }^{\mathrm{O}} \mathrm{B}\right)$ showed a decrease with storage. But the rate of decline was lesser in case of Benzyl adenine x $50 \mu$ LDPE $\left(6.9^{\mathrm{O}} \mathrm{B}\right)$ followed by Aloevera gel $\mathrm{x}$ $50 \mu \operatorname{LDPE}\left(6.83^{\mathrm{O}} \mathrm{B}\right)$. There is a decline in titratable acidity of the fruits irrespective of the packaging practice and the post-harvest treatment subjected. However, the decline in titratable acidity was lesser in Salicylic acid $\mathrm{x}$ $25 \mu$ LDPE (0.363). Ascorbic acid content fell drastically with storage but lesser decline was observed in Aloevera x 50 $\mu$ LDPE (133.01), Aloevera gel x $25 \mu$ LDPE (), Benzyl adenine x 25 $\mu$ LDPE (126.58) and Salicylic acid x Aloevera gel (118.33). Hedonic scores based on organoleptic properties were maximum in $\mathrm{T}_{3} \mathrm{P}_{1}$ (5.87) followed by $\mathrm{T}_{1} \mathrm{P}_{1}(5.73)$ at $9^{\text {th }}$ day of storage.

\section{Acknowledgement}

Authors would like to acknowledge the support of Department of Post-Harvest Technology of Horticultural Crops, BCKV, for providing all the facilities during the research work. Immense support and valuable suggestions were given by my guide Prof. Jahangir Kabir for this study.

\section{References}

Ahmed, M.J., Singh, Z. and Khan, A.S. 2009. Postharvest Aloe vera gel coating modulates fruit ripening and quality of Arctic Snow nectarine kept in ambient and cold storage. Int. J. Food Sci. Technol., 44:1024-1033.

Ahmed, M.N. 1998. Studies on the effect of post-harvest application of polyamines and antioxidants on the shelf life of Mango (Mangifera indica L.) cv. Baneshan. M.sc. Thesis., Submitted to Acharya N.G. Ranga Agricultural University, Hyderabad.
Anonymous. 2015. Indian Horticultural Database, Guava, www.nhb.gov.in.

Apelbaum, A. and Yang, S.F. 1981. Biosynthesis of stress ethylene induced by water deficit. Plant Physiol., 68:954956.

Apelbaum, A. and Yang, S.F. 1981. Biosynthesis of stress ethylene induced by water deficit. Plant Physiol., 68:954956.

Arberg, B. 1981. Plant growth regulators: Mono substituted benzoic acid. Swedish Agric. Res., 11:93-105.

Bassetto, E., Jacomino, A.P., Pinheiro, A.L. and Kluge, R.A. 2005. Delay of ripening 'Pedro Sato' guava with 1methylcyclopropene. Postharvest Biol. Technol., 35: 303-308.

Bisen, A. and Pandey, S. K. 2008. Effect of post-harvest treatments on biochemical and organoleptic constitutes of Kagzi lime fruits during storage. J. Hort. Sci., 3: 53-56.

Castillo, S., Navarro, D., Zapata, P.J., Guillen, F., Valero, M., Serrano, D. and Martinez-Romero. 2010. Antifungal efficacy of Aloe vera in vitro and its use as a postharvest treatment to maintain postharvest table grape quality. Postharvest Biol. Technol., 57(3). 183188.

Dang, K.T.H., Singh, Z. and Swinny, E.E. 2008. Edible coatings influence fruit ripening, quality, and aroma biosynthesis in mango fruit. J. Agric. Food Chem., 56: 1361-1370.

Jacomino, A. P., Minami, K., Sarantópoulos, C. I. G., De, L., Sigrist, J. M.M. and Kluge, R. A. 2001.Senorial characteristics of 'Kumagai' guavas submitted to passive modified atmosphere in plastic packages. Journal Plastic Film Sheeting, Lancaster, 17: 117.

Jayachandran, K.S., Srihari, D. and Reddy, Y.N. 2007. Post-harvest application of 
selected antioxidants to improve the shelf life of guava fruit. Acta Horticulturae, 735: 627-632.

Kaur, S., Arora, N.K., Boora, R.S., Dhaliwal, H.S., Gill, M.I.S. and Mahajan, B.V.C. 2014. Effect of perforated and nonperforated films on the quality and storage life of guava fruits. Indian $J$. Hort., 71(3): 390-396.

Kore, V.T. and kabir, J.2011. Influence of waxing and polyethylene packaging on shelf life of guava. Crop Res., 41-98102.

Kumar,P., Ram, B.R., Durivedi, D.H., Gautam, S.K and Singh, N. 2015. Response of different plant bioregulators for retaining the marketability of guava (Psidium guajava L.) fruits cv. CISH G-1 stored under ambient temperature. Int. $J$. Agric. Sci., 11(1):185-188.

Mani, A., Jain, N., Singh, A.K. and Sinha, M.2017. Effects of Aloevera Edible Coating on Quality and Postharvest Physiology of Ber (Zizyphus mauritiana Lamk.) under Ambient Storage Conditions, Int. J. Pure App. Biosci. 5(6):43-53.

Martínez-Romero, D., Alburquerque, N., Valverde, J. M., Guill_en, F., Castillo, S., Valero, D. 2006. Postharvest sweet cherry quality and safety maintenance by Aloe vera treatment: a new edible coating. Postharvest Biol. Technol., 39:93-100.
Misir, J., Brishthi, F.H and Hoque, M.M. 2014.Aloe veragel as a Novel Edible Coating for Fresh Fruits. Amer. J. Food Sci. Technol., 2(3): 93-97.

Neeraj, M.S., Joon, and Bhatia, S.K. 2003. Use of plastics in fruit packaging: A review. Haryana J. Hort. Sci., 32 (1/2):1-7.

Patel, R.K., Singh, Akath, Yadav, D.S., Bhytar, Deka, M. and Bidyut, C. 2009. Waxing, lining and polyethylene packaging on shelf life in juice quality of passion fruit. J. Food Sci. Tech., 46(1): 70-74.

Paull, R. E. and Goo, T. 1983. Relationship of guava (Psidium guajava L.) fruit detachment force to the stage of fruit development and chemical composition. HortScience., 18:65-67.

Rangana S. 1977. Ascorbic acid. Manual analysis of fruit and vegetable products. Tata McGraw-Hill Publish. Comp. Ltd., New Delhi. pp. 94-101.

Srivastava, M. K. and Dwivedi, U. N. 2000. Delayed ripening of banana fruit by salivylic acid. Plant Sci., 158: 87-96.

Van Staden, J. and Joughin, J.I. 1990. Plant Growth Regulation. In: Synthetic Plant Growth Regulators. M. Halman (ed), 7:117-128.

Zhang, Y., Chen, K., Zhang, S. and Ferguson, I. 2003. The role of salicylic acid in postharvest ripening of Kiwifruit. Postharvest Biol. Technol., 28: 67-74.

\section{How to cite this article:}

Manisha Ch. Momin, Jahangir Kabir and Alemmoa R. Jamir. 2018. Effect of Different PostHarvest Treatments and Prepackaging on Storage Behavior of Guava (Psidium guajava) cv. Khaza. Int.J.Curr.Microbiol.App.Sci. 7(01): 3186-3195. doi: https://doi.org/10.20546/ijcmas.2018.701.380 